is therefore highly probable that, as in the case of the $\rho$ Ophiuchi nebula described by Slipher (NATURE, vol. xcviii., p. 236), the nebula shines by reflected light of the star which it encloses. Other nebulæ have also been investigated, and some of them show feeble traces of bright nebular lines in addition to continuous spectrum. Very long exposures were of necessity given in taking the photographs, and it is still uncertain to what extent the photographed spectrum is influenced by light of the associated star which is diffused in the earth's atmosphere.

Imperial Astronomical Society of Russia.-A cordial welcome will be extended to the bulletins of the Imperial Astronomical jociety of Russia, the first number of which has recently been distributed. It contains a series of notes by $M$. Viliev, including an ephemeris of the planet (67) Asia, a search ephemeris of comet I846 IV. (De Vico), and a note on the possible return of the comet of $\mathbf{I}_{532}$. In opposition to Olbers, M. Viliev finds reason to believe that the comet of 1661 may have been a return of that of $I_{532}$, in which case its reappearance would be due about the present time; it remains, however, to make a new reduction of the observations made by Hevelius in I66I, and to calculate the perturbations during the three revolutions. A further note refers to the central line of the total eclipse of the sun of May 28-29, I9I9. One of the notes is in English, and the remainder in French.

Monthly Star Maps for I9I 7 .-In response to requests from naval and military officers and others, the annual publication of the Scottish Provident Institution has again taken the form of a star atlas and astronomical calendar, which has been prepared for the twentieth year in succession by Dr. Blaikie. In addition to the monthly maps, showing the stars in the now familiar gold on dark blue, there is a stereo. graphic projection intended for the solution of many problems for which the celestial globe is ordinarily employed. There are the usual tables relating to the sun, moon, and planets, and these, together with the interesting series of explanatory notes, form an admirable popular guide to the heavens. This publication has doubtless done much to encourage a general interest in observational astronomy, and its usefulness in this respect might be increased if it were made available to anyone who was prepared to pay for it.

\section{SCIENCE LECTURES TO THE TROOPS IN FRANCE.}

$A^{T}$ the invitation of the War Office, the Young A Men's Christian Association recently organised a special service of lecturers to visit suitable centres in France for periods varying from a fortnight to three months or more in order to provide the troops behind the line with recreation of a thoughtful kind. The lectures were arranged because of a desire expressed by many of the troops for occasional entertainment of a more solid or instructive character than is offered by moving pictures and concert parties. Their aim has been not merely to afford amusement to the men in their unoccupied hours, but to give an understanding of the causes and aims for which our troops are fighting, and to deal with military, naval, and political history, with science, literature, travel, and other subjects of general interest. The scheme has received the hearty support of the universities, the vice-chancellor of each of which has appointed a special committee to nominate lecturers. The details of arrangement have been in the hands of Prof. Gilbert NO. 2474, VOL. 99]
Murray for the War Office Educational Committee and of Mr. Basil Yeaxlee for the Y.M.C.A.

In connection with this scheme a number of lectures upon scientific subjects have been, and are being, given at base camps and other centres in France. Among the science lecturers who have already completed their courses are Prof. W. Bateson, Prof. Alex. Findlay, Prof. R. A. Gregory, Mr. J. Humphreys, Prof. O. T. Jones, Rev. T. E. R. Phillips, Prof. E. B. Poulton, Mr. W. E. Whitehouse, and Dr. F. Womack. Lectures have been given to the officers as well as to the men upon such subjects as heredity, chemistry of daily life, the sun, moon, planets, and stars, primitive astronomy, protective resemblance, war among animals, the life of a river, rocks and soils of northern France, the Great Ice Age, climate and vegetation, mechanical contrivances of plants, and so on.

The lectures are given in Y.M.C.A. huts, and are usually illustrated with lantern-slides. They have proved remarkably successful, and in most cases the huts have been filied with men who listened with attention and intelligent interest to simple discourses upon natural facts and phenomena and their scientific interpretation. Even when other attractions, such as concerts, moving pictures, and revues have been going on at the same time, large audiences have attended the science lectures, and have thus shown the existence of a real demand for more thoughtful recreation. The welfare work of the Y M.C.A. with the troops abroad is admirable in every respect, and the scheme of lectures now in operation merits all the assistance and encouragement which men of science can give it.

Although a few separate lectures are given to officers, most of them are delivered to the men, and officers are rarely present at them, though they are attracted by concert parties and like entertainments. It ought not to be supposed that the officers of our Army are less interested in scientific subjects than are the men of the rank and file, and their absence from lectures may be due to the fact that the Y.M.C.A. huts are regarded as places of recreation for the men only. As, however. Mr. McCowen, the chief secretary of the Y.M.C.A. in France, reports that the lecture scheme has succeeded almost beyond expectation, it would be worth while to develop the scheme still further by arranging more lectures for officers, not so much for purpeses of instruction as to excite interest in scientific matters.

Of course, lectures on history, literature, the allied countries, and similar subjects have also bęen delivered, and, on the whole, historical subjects are probably the most popular. There is no doubt, however, that the science lectures have been a source of pleasure and enlightenment to thousands of our troops at the base camps and further up the line, and the Y.M.C.A. is performing a very useful service in organising them. The work is of such decided educational value that it shou'd receive practical support from the State in the form of grants. With so large a part of our population serving with the forces at home and abroad, it should be possible for the Board of Education to make the Y.M.C.A. an education authority, and provide a substanitial part of the funds required to carry on and extend the educational enterprise so successfully begun.

\section{NANNA'S CAVE, ISLE OF CALDEY.}

CALDEY ISLAND, in Carmarthen Bay, two miles south of Tenby, has been occupied since the prehistcric period, and, as is shown by the raised beaches in the vicinity, has been exposed to periodical eleva- 
tion and depression. From time to time caves have been found in the Carboniferous limestone. Two of these were examined by a local clergyman about the middle of the last century, but the exploration was carried out in an unscientific way, and the remains discovered, without precise identification or record of stratification, are now deposited in the Tenby Museum. A more careful examination of the rock shelter, lknown as Nanna's Cave, has recently been made by local archæologists, and the results are described in a paper by $\mathrm{Mr}$. A. L. Leach, reprinted from Archaeologia Cambrensis for July, rg16. Remains of two skeletons, one female, the other male, were found. The female skull presents no characters which enable us to separate it from modern British skulls, or from remains which have been found in Neolithic or later Palasolithic deposits. It may be as old as the Aurignacean; but it showed no character which would disprove it being of Neolithic or historic age. In association with it was found a skilfully struck flint flake, similar to that obtained from the Hoyle Cave near Tenby, which is probably of the late Palæolithic age. This fact, however, is not conclusive of the age of the human remains. In the Romano-British age the cave was again occupied, and some fragments of pottery of that period formed parts of an olla, or cooking-pot, and a mortarium, probably used for rubbing down fruits and other soft food.

\section{POTASH FERTILISERS FROM FELSPARS.}

THE dearth of potassium salts in this country owing to the war has caused renewed attention to be devoted to the possibilities of preparing soluble potassium salts from the large deposits of felspar which are found in certain parts of the country. The problem has occupied the attention of chemists intermittently for many years, but the processes devised in the past have proved commercially unsuccessful, owing largely to the failure to obtain, along with the potash salts, other saleable products which might share the cost of manufacture. This difficulty would appear to have been largely overcome in the process patented by Mr. J. Rhodin, a Swedish inventor, in which, along with the soluble potassium salts, a marketable white cement is obtained. The successful results obtained by this process with Swedish felspars have been brought to the notice of the Board of Agriculture and Fisheries, and under the auspices of a subcommittee of the Fertilisers Committee of the Board further tests with British felspars from Roche, in Cornwall, and Loch Eriboll, in Sutherlandshire, have been carried out, the results of which are summarised in the February issue of the Journal of the Board of Agriculture.

The Roche felspar, containing ro.s per cent. $\mathrm{K}_{2} \mathrm{O}$, yielded 75 per cent. in a soluble form, whilst the Loch Eriboll spar, with 8.6 per cent. $\mathrm{K}_{2} \mathrm{O}$, gave 60 per cent. soluble. A Swedish spar, with 12.9 per cent. $\mathrm{K}_{2} \mathrm{O}$, yielded 54 per cent. in a soluble form. Expert opinion described the cement as a true hydraulic cement, of satisfactory colour, but of much lower tensile strength than Portland cement.

As the result of its examination, the sub-committee expresses the opinion that encouragement should be given to any movement for the manufacture of potash and white cement by the Rhodin process on a commercial scale, and that in the event of a public company applying to the Treasury for permission to raise capital to work this process, the application should receive the strong support of the Fertilisers Committee.

NO. 2474, VOL. 99]

\section{THE NATURAL SCIENCES IN PUBLIC} SCHOOLS. ${ }^{1}$

Age Limits for School Science.

THE teaching of natural science in public schools is of recent growth. Until quite recently most of the boys who took up this subject did so with the intention of making use of the training in their future careers. Even now, in some public schools, the number of boys learning science is small. It is, however, becoming recognised that science should form part of every boy's general education. For this reason it is necessary to put some, at least, of a koy's general training in science before the age at which specialising should be allowed. Too early specialising is bad policy: the age at which this may be begun by the average boy is about sixteen and a half years.

Before this age (or its equivalent for forward or backward boys) the pupil should have spent, on an average, four hours a week at science for a period of at least two years, and six hours a week for a further two years. Thus the worls should be begun in the preparatory schools. The only work recommended to be done there is in nature-study and practical measurements. See "Nature-Study in Preparatory Schools " and " The Correlation of Mathematical and Science Teaching" (Bell and Sons, each 6d.).

After a boy has reached such a standard of general education that he may be allowed to specialise to a certain extent, he should have the opporturity of devoting about eight hours a week to science if he chooses to do so. At a still later stage the specialisation should be more marked in the case of those who choose a scientific career.

\section{Science in Examinations.}

If these ideals can be reached by any means other than making science compulsory in examinations, those means should be employed. If they cannot, compulsion by examination regulations must be applied. But this should then be recognised as a necessary evil. It is possible that some system of inspection of schools by examining bodies, combined with the granting of certificates on the recommendation of a properly qualified master, might prove to be the solution of the difficult problem of insisting on science being learnt by every boy, without the restrictions necessarily imposed when there are examination syllabuses. But the details of such a scheme would require careful thinking out.

But there is, at present, a vet stronger argument against the attempt to foster the teaching of science by making the subject compulsory in examinations. So long as instruction in science was given only tu those who were destined for a scientific career, it was natural (if, perhaps, unwise) to aim chiefly at inculcating scientific method, with a certain disregard of general knowledge of natural phenomena. This was done, for the most part, by logical courses in hydro. statics, heat, light, electricity, and chemistry. But in some cf the schools where science has already become a compulsory subject it has been recognised that such courses may be unsuitable for the non-scientific mind. The attempt is made to arouse a boy's appreciation of the value and scope of science rather than to teach him the elements of a subject which he will drop even before leaving school. In such schools a considerable proportion of his science hours is devoted to studying subjects ranging from the universe to the electron: astronomy, geology, biology, physio-

I Abridged from a memorandum drawn up by the committee of the Ascociation of Public School Science Masters to serve as the text of the evidence offered on behalf of the association to the Goveriment Committee on the Teaching of Science. 